\title{
Health literacy and adherence to treatment of patients with heart failure*
}

\author{
Literacia em saúde e adesão ao tratamento de pacientes com insuficiência cardíaca \\ Literacia en salud y adhesión al tratamiento de pacientes con insuficiencia cardiaca
}

How to cite this article:

Oscalices MIL, Okuno MFP, Lopes MCBT, Batista REA, Campanharo CRV. Health literacy and adherence to treatment of patients with heart failure. Rev Esc Enferm USP. 2019;53:e03447. DOI: http://dx.doi.org/10.1590/S1980-220X2017039803447

\section{Monica Isabelle Lopes Oscalices ${ }^{1,2}$ \\ Meiry Fernanda Pinto Okuno ${ }^{1}$ \\ D Maria Carolina Barbosa Teixeira Lopes $^{1}$ \\ Ruth Ester Assayag Batista ${ }^{1}$ \\ D Cassia Regina Vancini Campanharo ${ }^{1}$}

\footnotetext{
* Extracted from the dissertation:

"Reinternação e adesão ao tratamento de pacientes com insuficiência cardíaca após orientação de alta e contato telefônico de enfermagem”, Escola Paulista de Enfermagem, Universidade Federal de São Paulo, 2017.

${ }^{1}$ Universidade Federal de São Paulo, Escola Paulista de Enfermagem, São Paulo, SP, Brazil.

2 Instituto Dante Pazzanese de

Cardiologia, São Paulo, SP, Brazil.
}

\section{ABSTRACT}

Objective: To relate the level of functional health literacy with adherence and barriers to non-adherence, rehospitalization, readmission and death in patients with heart failure. Method: A cross-sectional, analytical study with patients admitted to the emergency room with a diagnosis of heart failure. Literacy was assessed by the Newest Vital Sign. Patient adherence to medication treatment and barriers to non-compliance were assessed 90 days after discharge by the Morisky-Green test and the Brief Medical Questionnaire, respectively. Results: 100 patients participated in the study. The mean age was 63.3 years $( \pm 15.2)$, with a predominance of white women. Medication adherence was low in $41.1 \%$ of participants, of which $55.9 \%$ presented inadequate literacy. Re-hospitalization and death were present in patients with inadequate literacy $(p<0.001)$. Conclusion: The low level of literacy was directly related to lower adherence and the presence of barriers to medication adherence, as well as higher rehospitalization rates and death.

\section{DESCRIPTORS}

Health Literacy; Health Education; Treatment Adherence and Compliance; Emergency Nursing. 


\section{INTRODUCTION}

Health literacy (HL) is understood as the degree of ability individuals possess to obtain, process, and understand basic health information in order to be able to make health-related decisions through the ability to understand and interpret numbers, texts and documents ${ }^{(1)}$. Thus, HL has a strong social component related to the individual's ability to make fundamental decisions in taking responsibility for their health, and finally, how the patient can apply the necessary health care ${ }^{(2)}$.

The literature demonstrates that individuals with low HL may present problems in understanding diseases, reading package inserts and medication labels, recall of treatment and understanding doses and schedules, and difficulties in interpreting vital signs such as blood pressure, heart rate and capillary glycemia tests ${ }^{(2)}$. In addition, low $\mathrm{HL}$ is related to lower demand for health services for prevention, less knowledge about chronic disease, less healthy life choices, poor adherence to medications and poorer understanding of their use, lower self-management of the disease and a higher rate of hospital admission and mortality. This results in higher costs related to chronic disease care, in addition to influencing communication with health professionals ${ }^{(3-5)}$.

Communication is known for its relevance in the relationship between patients and the health team, and low literacy can affect this interaction, impacting the therapeutic process. It is an important factor in the effective understanding of information related to the disease, contributing to the individual being able to make the best decision regarding the proposed treatment ${ }^{(3)}$.

Among chronic diseases, decompensated Heart Failure (HF) is responsible for nearly 1 million annual hospitalizations in the US due to decompensation, and is directly related to medication treatment adherence and to significant changes in lifestyles involved in non-pharmacological care for the control of $\mathrm{HF}^{(6)}$. This study indicates that high health literacy is associated with a higher index of knowledge about HF by the patients, better medication adherence, as well as a better non-pharmacological management such as water and salt restriction. Thus, low literacy may be related to a higher mortality rate and hospitalizations due to decompensated $\mathrm{HF}^{(7)}$.

National studies have shown that the guidelines used by nurses are frequent practices for patients with $\mathrm{HF}^{(8-9)}$. It is important that the nurse knows the HL level of the individual, since the implementation of targeted interventions can increase patients' adherence to treatment and decrease the rates of rehospitalization and death ${ }^{(4-5)}$. In view of the above, the purpose of this study was to associate the functional literacy level in health with medication adherence, the barriers to non-adherence, rehospitalization and mortality in patients with heart failure.

\section{METHOD}

\section{Study DESIGN}

A cross-sectional and analytical study.

\section{SCENARIO}

Conducted in the emergency room of a public hospital specialized in cardiology.

\section{Data collection}

The included patients were selected at the time of hospital discharge, were admitted to the emergency room with a diagnosis of decompensated heart failure according to a clinical-hemodynamic profile, during the period from January to December 2016, aged over 18 years, and had a phone number. A sample of 100 selected patients was aggregated, and the losses presented during the study period were exclusively due to death.

\section{INSTRUMENTS}

The sociodemographic variables studied were age, gender, education, occupation and family income. Three instruments were used; the first to evaluate literacy, the second to assess compliance with medication treatment, and the third to identify barriers to adherence.

The HL assessment was performed during hospitalization using the Newest Vital Sign (NVS), an instrument that provides patients with nutritional information on a label on an ice cream carton, which should be used to answer six questions. The questions are asked by the investigator, and one point is assigned for each correct answer and zero points for each wrong answer. When no response is achieved or only one response is correct, the patient is categorized as marginal literacy, between 2 and 3 correct responses indicate limited literacy, and 4 or more correct responses demonstrate high health literacy ${ }^{(10)}$. This instrument has an administration time of 6 minutes, is widely accepted for evaluating health literacy, and is translated into several languages, including Portuguese ${ }^{(10-11)}$. Patient adherence to medication treatment was assessed by the Morisky-Green Test (MGT), which consists of four questions: "1) Do you sometimes have trouble remembering to take your medication? 2) Do you sometimes neglect to take your medicine? 3) When you are feeling better, do you sometimes stop taking your medicine? 4) If you sometimes feel worse while taking the medication, do you stop taking it?". The patient is classified in the high adherence group when the answers to the four questions are negative, when one or two responses are positive in the moderate adherence group, and if three or four responses are positive in the low adherence group. This instrument is considered the gold standard for evaluating medication adherence in the SAH population ${ }^{(12)}$ and has already been used for evaluating patients with $\mathrm{HF}^{(13)}$.

The Brief Medication Questionnaire (BMQ) was used to identify possible barriers to adherence to treatment by the patient. The instrument is composed of three domains, namely: Regimen Domain, which evaluates the patient behavior related to adherence to the prescribed treatment regimen; Belief Domain, which assesses the level of belief that the patient has regarding the efficacy of the treatment and opinions about unwanted side effects; and the Remembrance Domain, which identifies problems regarding difficulty of remembering to 
medicate. The presence of positive response in the domains identifies a barrier to the prescribed treatment regimen. This instrument was successfully validated in patients with chronic diseases such as hypertension ${ }^{(14)}$.

The evaluation of adherence and barriers to adherence to medication treatment by the MGT and BMQquestionnaires was performed 90 days after hospital discharge through telephone contact from the researcher, who also identified the occurrence of readmissions and death.

The primary outcome considered was the relationship between literacy, adherence and barriers to medication adherence, and the relationship between literacy levels and readmission rates and death as secondary outcomes, being analyzed at 7,30 and 90 days after hospital discharge by phone contact.

\section{DATA ANALYSIS AND PROCESSING}

An analysis of the continuous variables was performed by calculating the mean, standard deviation, median, minimum and maximum, while frequency and percentage were calculated for the categorical variables. The Generalized Estimating Equation Model (GEE) was used to associate literacy with medication adherence and barriers to adherence and to associate literacy with mortality and readmission in 90 days. A significance level of $5.0 \%$ ( $\mathrm{p}$-value $<0.05 \%$ ) was considered.

\section{ETHICAL ASPECTS}

The data collection began after approval from the Research Ethics Committee of the proposing institutions under the protocol of opinion no. 922.744 of 2014 , according to the precepts of Resolution no. 466/2012 of the National
Health Council. All study participants signed the Informed Consent Form (ICF).

\section{RESULTS}

A total of 100 patients, mean age 63.3 years $(S D \pm 15.2)$, with a female predominance of $57.0 \%$, ethnically distributed among $41.0 \%$ white, $39.0 \%$ black, $19.0 \%$ mulatto and $1.0 \%$ Asian. Among the personal antecedents, $97.0 \%$ of the individuals had systemic arterial hypertension, $59.0 \%$ diabetes mellitus, $76.0 \%$ dyslipidemia, $29.0 \%$ were smokers, and $14.0 \%$ were obese. All patients were hospitalized with a diagnosis of decompensated heart failure, and classified in $60 \% \mathrm{HF}$ profile $\mathrm{B}, 30 \% \mathrm{HF}$ profile $\mathrm{C}$, and $10 \% \mathrm{HF}$ profile $\mathrm{L}$.

In relation to the educational level of the population, $2.0 \%$ of the participants had more than 16 years of study, $18.4 \%$ between 8 and 15 years, $37.3 \%$ between 5 and 8 years, $36.3 \%$ had under to 4.9 years of study, and $6.0 \%$ had no formal study. Regarding occupation, most of the individuals performed household activities $(26.0 \%)$ or were retired (26.0\%). Medications were fully funded for $46 \%$ of patients, $35 \%$ received medications free of charge, and $19.0 \%$ were partially funded. Almost half of the population (48.0\%) had income between one and two minimum salaries.

In the HL analysis during hospitalization using the NVS test, $11.0 \%$ of the patients presented adequate health literacy, $21.0 \%$ were categorized as having marginal health literacy, and $68.0 \%$ of the patients had inadequate health literacy.

The results showed that there is a significant relationship between education and literacy. Patients with less studying had a higher percentage of inadequate health literacy than the other education groups ( $\mathrm{p} \leq 0.001)$, as observed in Table 1 .

Table 1 - Education and literacy level in patients hospitalized in emergency for HF - São Paulo, SP, Brazil, 2016.

\begin{tabular}{|c|c|c|c|c|c|}
\hline \multirow{3}{*}{ Education } & \multicolumn{3}{|c|}{ Health Literacy } & \multirow{3}{*}{$\begin{array}{c}\text { Total } \\
\mathrm{n}=100(\%)\end{array}$} & \multirow{3}{*}{ p-value } \\
\hline & Adequate & Marginal & Inadequate & & \\
\hline & $n=11(\%)$ & $\mathrm{n}=21(\%)$ & $n=68(\%)$ & & \\
\hline 0 to 4.9 & $1.0(9.1)$ & $2.0(9.5)$ & $37.0(54.4)$ & $40(40.0)$ & \multirow[t]{3}{*}{$<0.0001$} \\
\hline 5 to 8.9 & $1.0(9.1)$ & $18.0(85.7)$ & $17(25.0)$ & $36(36.0)$ & \\
\hline$>9$ to 11.9 & $9.0(81.8)$ & $1.0(4.8)$ & $14(20.6)$ & $24(24.0)$ & \\
\hline
\end{tabular}

The evaluation of medication adherence and barriers to therapy was performed after 90 days of hospital discharge with 95 patients (Table 2), as five individuals from the total sample died in this period.

Regarding HL level and adherence and barriers for medication adherence, it is observed that a large part of the participants were classified as low adherence, and the majority of these is in patients with inadequate health literacy, as observed in Table 3.

When the level of functional literacy in health was associated with the occurrence of readmission and death at 7,30 and 90 days, it was observed that patients with inadequate health literacy presented higher percentages of readmission $(p<0.001)$ and death $(p<0.001)$ after 30 and 90 days of discharge from the hospital, as can be seen in Table 4 .
Table 2 - Adherence to treatment of patients with heart failure and barriers to adherence, according to the Morisky-Green Test and Brief Medical Questionnaire, respectively - São Paulo, SP, Brazil, 2016.

\begin{tabular}{lc}
\hline Medication Adherence & $\mathbf{n}(\%)$ \\
\hline Adherent & $24(25.3)$ \\
Moderate adherence & $32(33.7)$ \\
Low adherence & $39(41.1)$ \\
\hline
\end{tabular}

Barriers to medication adherence

Regimen Barrier

56 (58.9)

Belief Barrier

15 (15.8)

Recall Barrier

37 (38.9) 
Table 3 - Adherence of patients with heart failure to treatment and types of barriers to adherence according to levels of functional health literacy - São Paulo, SP, Brazil, 2016.

\begin{tabular}{|c|c|c|c|c|}
\hline \multirow[b]{2}{*}{ Medication adherence/Types of barriers } & \multicolumn{3}{|c|}{ Health Literacy } & \multirow{2}{*}{$\begin{array}{c}\text { Total } \\
\text { n=95 }(\%)\end{array}$} \\
\hline & $\begin{array}{l}\text { Adequate } \\
n=11(\%)\end{array}$ & $\begin{array}{c}\text { Marginal } \\
n=21(\%)\end{array}$ & $\begin{array}{c}\text { Inadequate } \\
n=63(\%)\end{array}$ & \\
\hline \multicolumn{5}{|l|}{ Morisky-Green Test } \\
\hline High adherence & $9.0(81.8)$ & $6.0(28.6)$ & $9.0(13.2)$ & $24.0(24.0)$ \\
\hline Moderate adherence & $1.0(9.1)$ & $15.0(71.4)$ & $16.0(23.5)$ & $32.0(32.0)$ \\
\hline Low adherence & $1.0(9.1)$ & - & $38.0(55.9)$ & $39.0(39.0)$ \\
\hline \multicolumn{5}{|l|}{ Brief Medication Questionnaire } \\
\hline Regimen Barrier & $2.0(18.2)$ & $11.0(52.4)$ & $43.0(63.2)$ & $56.0(56.0)$ \\
\hline Belief Barrier & - & - & $15.0(22.1)$ & $15.0(15.0)$ \\
\hline Recall Barrier & $1.0(9.1)$ & - & $36.0(52.9)$ & $37.0(37.0)$ \\
\hline
\end{tabular}

Table 4 - Readmission and death of patients with heart failure according to levels of functional health literacy - São Paulo, SP, Brazil, 2016.

\begin{tabular}{|c|c|c|c|c|}
\hline & \multicolumn{3}{|c|}{ Health Literacy } & \multirow[b]{2}{*}{ P-value } \\
\hline & $\begin{array}{l}\text { Adequate } \\
\mathrm{n}=11(\%)\end{array}$ & $\begin{array}{l}\text { Marginal } \\
\mathrm{n}=21(\%)\end{array}$ & $\begin{array}{c}\text { Inadequate } \\
\mathrm{n}=63(\%)\end{array}$ & \\
\hline \multicolumn{5}{|l|}{ Seven days } \\
\hline Readmission & 0 & 0 & 0 & - \\
\hline Death & 0 & 0 & 0 & - \\
\hline \multicolumn{5}{|l|}{30 days } \\
\hline Readmission & 0 & 0 & 2 & 0.4580 \\
\hline Death & 0 & 0 & 0 & - \\
\hline \multicolumn{5}{|l|}{60 days } \\
\hline Readmission & 0 & 0 & 26 & 0.0001 \\
\hline Death & 0 & 0 & 5 & 0.0001 \\
\hline
\end{tabular}

\section{DISCUSSION}

With the increase in HF patients and also the increase in health education strategies for the adherence of these patients to treatment, a reduction in readmissions and deaths are sought ${ }^{(8)}$, and health literacy can be an important instrument to evaluate and adapt the strategies and thus optimize the individualized therapeutic plan of each patient. In view of this scenario, this study proposed to evaluate the health literacy levels of patients with $\mathrm{HF}$ and to associate these levels with the rate of drug adherence and barriers to therapy, readmissions and death after discharge from the emergency department.

In the demographic and clinical profile of the patients in this study, older adults, hypertensive, diabetic and dyslipidemic women predominated; characteristics which are consistent with other studies and which present the following data: $5 \%$ of the older adults up to 75 years old and up to $20 \%$ older than 80 years have $\mathrm{HF}^{(15)}$. This situation may be associated with greater patient survival and a higher prevalence of comorbidities such as hypertension, diabetes and dyslipidemia. This corroborates findings in the literature ${ }^{(15)}$, which show that patients present multiple concomitant diseases with HF, mainly SAH, which is one of the main risk factors for developing $\mathrm{HF}^{(15-16)}$.

The majority of patients had 5 to 8 years of study, and $6 \%$ had no formal study, which is a similar result found in a study that evaluated the epidemiological profile of older adults with $\mathrm{HF}$ in an Intensive Care Unit in the state of Bahia, demonstrating that these hospitalized patients mostly had incomplete secondary education ${ }^{(17)}$. Although there is no direct relationship between education and the occurrence of the disease, low education may be associated with a lack of understanding of the need to seek immediate medical attention at the first signs of decompensation ${ }^{(18)}$.

This study revealed that most of the participants (68.0\%) had inadequate health literacy, which is a similar finding to another study ${ }^{(17)}$. Inadequate health literacy is a matter of concern and permeates health actions and strategies for disease and injury prevention and self-care promotion, and is directly related to the patient's knowledge about the control of their disease ${ }^{(3)}$. Nurses have an important role in this context because they can establish appropriate interventions for treatment through educational strategies, thus favoring understanding of the disease, greater therapeutic adherence and self-care in relation to $\mathrm{HF}^{(19)}$. The main objective of nursing education for patients with $\mathrm{HF}$ is that they understand the importance of adherence to treatment and the signs and symptoms of decompensation ${ }^{(19)}$. Health education can positively impact the adherence to $\mathrm{HF}$ treatment of patients with low HL, such as the use of adequate vocabulary to levels of literacy, visual communication and continuous feedback ${ }^{(20)}$. 
Literature reveals that the literacy level of the individual is related to their education ${ }^{(8,21)}$, and that the years of studies can be predictors of different levels of literacy ${ }^{(8)}$, confirming data observed in this study where patients with an adequate literacy level had more years of formal study, between 9 and 12 years. It is important to highlight the importance of this data when evaluating the low level of education of Brazilians, and the fact that this fact may be associated with the health of the population, especially with regard to understanding the disease and promoting health.

The highest percentage of medication adherence in the present study was also related to literacy levels, in which patients who had an adequate literacy level had greater adherence to drug treatment (88.1\%). In a Dutch metaanalysis in which 17 publications were analyzed, results on literacy and medication adherence were divergent, as they did not obtain clarity regarding the association of a higher level of literacy and medication compliance ${ }^{(22)}$. On the other hand, other studies on the subject refer to a positive link between higher level of literacy and greater adherence to treatment ${ }^{(8)}$. A randomized clinical trial with patients with $\mathrm{HF}$ aimed at analyzing the relationship between literacy, self-care and knowledge of HF, showed that a higher level of literacy was associated with greater medication adherence $^{(23)}$. Considering that HF is a chronic disease which requires frequent use of multiple medications and the need for continuous self-care, mainly related to changes in lifestyle, weight and food control, it is justifiable that a higher literacy level is associated with greater medication adherence, since the complexity of the treatment requires a greater understanding of the individual, and patients with lower degrees of literacy have a deficit in their comprehension and apprehension of content, making it difficult to learn management with the care that the $\mathrm{HF}$ requires. Although the medication adherence test used in the present study was developed and validated for patients with hypertension, there are already studies which used it for evaluating medication adherence in patients with heart failure ${ }^{(13-14)}$.

Regarding the barriers to medication adherence, those of regimen, belief and recall are more present in the individuals with inadequate health literacy, $63.2 \%, 22.1 \%$ and $52.9 \%$, respectively. The regimen barrier, which suggests difficulty in understanding patients' prescriptions and treatment guidelines, is present in $56 \%$ of the patients, of whom $63.2 \%$ presented inadequate literacy, which reinforces the link between the level of literacy, the patient's understanding of their illness and their low adherence to treatment. Such a result is similar to that found in a study which used instruments for assessing adherence and barriers to medication adherence and concluded that the presence of the barrier regimen was associated with poor medication adherence ${ }^{(12)}$.

The relationship between patients' beliefs about treatment and self-care is well known ${ }^{(24)}$. The belief barrier exposes patients' conviction regarding the proposed treatment and was presented in $22.1 \%$ of the patients with inadequate health literacy. For the recall barrier, this was observed in $52.9 \%$ of the patients who presented inadequate health literacy. Studies related to belief and recall barriers are scarce in the literature, but the existence of a barrier to adherence to treatment may be related to inadequate literacy.

The present study showed a significant association between literacy level and readmission levels after 90 days ( $p<0.001)$, and all patients who were readmitted had inadequate health literacy. Divergent results were obtained in an American cohort study which evaluated the relationship between health literacy and mortality outcomes and readmission of patients with $\mathrm{HF}$, and revealed that there is no relationship between the literacy level and the readmission rate ${ }^{(25)}$. The relationship between medication adherence and the self-care of $\mathrm{HF}$ patients with hospital readmission is well-known, justifying that patients with low literacy level and consequently lower understanding regarding medications and changes in lifestyle present higher levels of hospital readmission ${ }^{(7)}$.

The analysis of mortality after hospital discharge in up to 90 days showed that $5 \%$ of the patients died during this period, and all presented inadequate health literacy. A retrospective cohort study conducted in Colorado with 1,494 patients and published in 2015, correlated mortality and hospitalization of patients with literacy levels and showed a similar result regarding low literacy being related to higher rates of all-cause mortality in the study period ${ }^{(26)}$.

A similar retrospective cohort study published in 2015 with a sample of 1,379 patients hospitalized for $\mathrm{HF}$, analyzed the mortality and hospitalization of these patients over a period of 90 days and associated them with the levels of literacy ${ }^{(22)}$, corroborating the data of the present study when evidencing that patients with lower levels of literacy had higher mortality rates 90 days after hospital discharge. These differences in the results found are justified by the high mortality of patients after hospitalization for $\mathrm{HF}$ and by the various factors which influence mortality, such as the presence of comorbidities, the number of hospitalizations due to decompensation, polypharmacy and non-pharmacological care ${ }^{(27)}$.

Non-pharmacological care consists of adequate water restriction, correct salt intake and daily weight control, meaning that it is directly related to behavioral change and life habits ${ }^{(28)}$. A systematic review article that analyzed 17 studies on self-care and chronic diseases, including HF, confirmed that the patient's actual self-care of the disease is directly related to the decrease in mortality and readmissions, thus constituting an important factor to be considered ${ }^{(28)}$, mainly because literacy is defined as applied health care ${ }^{(1)}$.

The clinical-hemodynamic profile proposed in the study evaluated clinical parameters for patient classification and has four profiles which can guide the chosen therapy and also the patient prognosis. Such an instrument is therefore extremely relevant regarding patient mortality, being that patients hospitalized with decompensated $\mathrm{HF}$ profile $\mathrm{C}$ are more likely to evolve to death ${ }^{(29)}$.

This study presents limitations of being performed in a single center, the reduced sample size, the follow-up time and the evaluation and individual relationship of health literacy to the mortality data, considering the multimorbidity of the studied patients.

Nurses have an important role in health education, especially in patients with chronic diseases such as HF. HL is 
related to health promotion and its high levels of adherence to treatment and decrease in the occurrence of readmissions and deaths in patients with HF. Given the above, and considering the scarcity of national literature, the importance of studies which subsidize elaborating health education strategies directed to the real needs of the population is evident ${ }^{(30)}$.

\section{CONCLUSION}

The study concluded that patients with HF who had an inadequate level of functional health literacy had lower medication adhesion and a greater number of barriers to nonadherence when tested after hospital discharge. During the 3-month follow-up of patients after hospital discharge, those with inadequate functional health literacy had a higher number of readmissions and evolution to death. Although the study makes it possible to relate functional health literacy with medication adherence, hospital readmission and death of patients with $\mathrm{HF}$, new studies evaluating other factors related to mortality and therapeutic adherence of these patients are necessary in order to better correlate functional literacy in patients with $\mathrm{HF}$.

\section{RESUMO}

Objetivo: Relacionar o nível de literacia funcional em saúde com a adesão e barreiras para a não adesão medicamentosa, a reinternação e o óbito em pacientes com insuficiência cardíaca. Método: Estudo transversal, analítico, com pacientes internados em serviço de emergência, com diagnóstico de insuficiência cardíaca. A literacia foi avaliada na alta pelo Newwest Vital Sign. A adesão do paciente ao tratamento medicamentoso e as barreiras para a não adesão foram avaliadas 90 dias após a alta por meio do teste de Morisky-Green e Brief Medical Questionnaire, respectivamente. Resultados: Participaram do estudo 100 pacientes. A média de idade foi 63,3 anos $( \pm 15,2)$, com predomínio de mulheres brancas. Em $41,1 \%$ dos participantes a adesão medicamentosa foi baixa, destes, $55,9 \%$ apresentaram inadequada literacia. A reinternação e o óbito estavam presentes nos pacientes com inadequada literacia $(\mathrm{p}<0,001)$. Conclusão: $\mathrm{O}$ baixo nível de literacia relacionou-se diretamente com menor adesão e presença de barreiras para a adesão medicamentosa, além de maiores índices de reinternação e óbito.

\section{DESCRITORES}

Alfabetização em Saúde; Educação em Saúde; Insuficiência Cardíaca; Cooperação e Adesão do Paciente; Enfermagem em Emergência.

\section{RESUMEN}

Objetivo: Relacionar el nivel de literacia funcional en salud con la adhesión y barreras para la no adhesión medicamentosa, el reingreso hospitalario y el fallecimiento en pacientes con insuficiencia cardiaca. Método: Estudio transversal, analítico, con pacientes hospitalizados en servicio de urgencias, con diagnóstico de insuficiencia cardiaca. La literacia fue evaluada en el alta por el Nerwest Vital Sign. La adhesión del paciente al tratamiento medicamentoso y las barreras para la no adhesión fueron evaluadas 90 días después del alta mediante la prueba de Morisky y el Brief Medical Questionnaire, respectivamente. Resultados: Participaron en el estudio 100 pacientes. El promedio de edad fue de 63,3 años, con predominio de mujeres blancas. En el 41,1\% de los participantes, la adhesión medicamentosa fue baja, de esos el 55,9\% presentaron inadecuada literacia. El reingreso y el fallecimiento estaban presentes en los pacientes con inadecuada literacia $(\mathrm{p}<0,001)$. Conclusión: El bajo nivel de literacia se relacionó directamente con menor adhesión y presencia de barreras para la adhesión medicamentosa, además de mayores índices de reingreso y el fallecimiento.

\section{DESCRIPTORES}

Alfabetización en Salud; Educación en Salud; Insuficiencia Cardíaca; Cumplimiento y Adherencia al Tratamiento; Enfermería de Urgencia.

\section{REFERENCES}

1. Centers for Disease Control and Prevention; National Center for Health Statistics. Healthy People 2010 [Internet]. Washington; 2000 [cited 2017 Oct 02]. Available from: https://www.cdc.gov/nchs/healthy_people/hp2010.htm

2. Maragno CAD, Luiz PPV. Letramento em saúde e adesão ao tratamento medicamentoso: uma revisão da literatura. Rev Iniciação Cient [Internet]. 2016 [citado 2017 out. 01];14(1):5-18. Disponível em: http://periodicos.unesc.net/iniciacaocientifica/article/viewFile/2672/2480

3. Passamai, MPB, Sampaio HAC, DiasAMI, Cabral LA. Letramento funcional em saúde: reflexões e conceitos sobre seu impacto na interação entre usuários, profissionais e sistema de saúde. Interface (Botucatu) [Internet]. 2012 [citado 2017 out. 02]; 16(41):301-4. Disponível em: http://www.scielo.br/scielo.php?script=sci_arttext\&pid=S1414$32832012000200002 \& \operatorname{lng}=$ en

4. Cavaco A, Santos AL. Evaluation of health literacy and the readability of information leaflets. Rev Saúde Pública. 2012;46(5):918-22. DOI: http://dx.doi.org/10.1590/ S0034-89102012000500019

5. Apolinario D, Braga RC, Magaldi RM, Busse AL, Campora F, Brucki S, et al. Short assessment of health literacy for Portuguese speaking adults. Rev Saúde Pública. 2012;46(4):702-11. DOI: http://dx.doi.org/10.1590/S0034-89102012005000047

6. Heidenreich PA, Albert NM, Allen LA, Bluemke DA, Butler J, Fonarow GC, et al. Forecasting the impact of heart failure in the United States: a policy statement from the American Heart Association. Circ Heart Fail. 2013;6(3):606-19. DOI: http://doi.org/10.1161/HHF.0b013e318291329a

7. Cajita MI, Cajita TR, Han HR. Health literacy and heart failure: a systematic review. J Cardiovasc Nurs. 2016;31(2):121-30. DOI: http://doi.org/10.1097/ JCN.0000000000000229

8. Souza PM, Queluci GC. A arte de cuidar em pacientes com insuficiência cardíaca na alta hospitalar: considerações para a prática assistencial na enfermagem. Rev Pesqui Cuid Fundam Online [Internet]. 2014 [citado 2017 set. 30];6(1):153-67. Disponível em: http://www.seer.unirio.br/index.php/cuidadofundamental/article/viewFile/2803/ pdf_1086

9. Mantovani VM, Ruschel KB, Souza EN, Mussi C, Rabelo-Silva ER. Treatment adherence in patients with heart failure receiving nurse-assisted home visits. Acta Paul Enferm [Internet]. 2015 [cited 2017 Sept 30];28(1):41-7. Available from: http://www.scielo.br/scielo.php?pid=S0103-21002015000100041\&script=sci_arttext\&tlng=en

10. Rodrigues R, Andrade SM, González AD, Birolim MM, Mesas AE. Cross-cultural adaptation and validation of the Newest Vital Sign (NVS) health literacy instrument in general population and highly educated samples of Brazilian adults. Public Health Nutr. 2017;20(11): 1907-13. DOI: 10.1017/S1368980017000787

11. Martins AC, Andrade IM. Adaptação cultural e validação da versão portuguesa de Newest Vital Sign. Rev Enferm Ref [Internet]. 2014 [citado 2018 jun. 05];(3):75-84. Disponível em: https://rr.esenfc.pt/rr/index.php?module=rr\&target=publicationDetails\&pesquisa=\&id_artigo=2468\&id_revista=24\&id_edicao=68 
12. Ben AJ, Neumann CR, Mengue SS. The Brief Medication Questionnaire and Morisky-Green Test to evaluate medication adherence. Rev Saúde Pública. 2012;46(2):27989. DOI: http://dx.doi.org/10.1590/S0034-89102012005000013.

13. Castro RA, Aliti GB, Linhares JC, Rabelo ER. Adesão ao tratamento de pacientes com insuficiência cardíaca em um hospital universitário. Rev Gaúcha Enferm [Internet] 2010 [citado 2018 jun. 05];31(2):225-31. Disponível em: http://www.scielo.br/scielo.php?script=sci_arttext\&pid=S1983-14472010000200004

14. Vancini-Campanharo CR, Oliveira GN, Andrade TFL, Okuno MFP, Lopes MCBT, Batista REA. Systemic Arterial Hypertension in the Emergency Service: medication adherence and understanding of this disease. Rev Latino Am Enfermagem. 2015;23(6):1149-56. DOI: http://dx.doi.org/10.1590/0104-1169.0513.2660

15. Nogueira PR, Rassi S, Corrêa KS. Perfil epidemiológico, clinico e terapêutico da insuficiência cardíaca em hospital terciário. Arq Bras Cardiol [Internet]. 2010 [citado 2017 set. 30];95(3):392-8.Disponivel em: http://www.scielo.br/scielo.php?script=sci_arttext\&pid=S0066-782X2010001300016

16. Rodríguez-Gázquez MA, Arredondo-Holguín E, Herrera-Cortés R. Effectiveness of an educational program in nursing in the self-care of patients with heart failure: randomized controlled trial. Rev Latino Am Enfermagem. 2012;20(2):296-306. DOI: http://dx.doi.org/10.1590/S0104-11692012000200012

17. Souza MP, Araújo SM, Dourado MB, Gama GGG. Perfil epidemiológico de idosos com insuficiência cardíaca na unidade de terapia intensiva. Rev Enferm Contemp [Internet]. 2017 [citado 2017 set. 30];6(1):42-8. Disponível em: https://www5.bahiana.edu.br/index.php/enfermagem/article/view/1164.

18. Almeida AP, Nunes BP, Duro SM, Facchini LA. Socioeconomic determinants of access to health services among older adults: a systematic review. Rev Saúde Pública. 2017;51:50. DOI: http://dx.doi.org/10.1590/s1518-8787.2017051006661

19. Costa YF, Araújo OC, Almeida LBM,Viegas SMG. O papel educativo do enfermeiro na adesão ao tratamento da Hipertensão Arterial Sistêmica: revisão integrativa da literatura. Mundo Saúde [Internet] 2014 [citado 2018 jun. 05];38(4):473-81. Disponível em: https://www.saocamilo-sp.br/pdf/mundo_saude/155566/A12.pdf

20. Wu JR, Holmes GM, DeWalt DA, Macabasco-O'Connell A, Bibbins-Domingo K, Ruo B, et al. Low literacy is associated with increased risk of hospitalization and death among individuals with heart failure. J Gen Intern Med [Internet]. 2013 [cited 2017 out. 01];28(9):1174-80. Available from https://www.ncbi.nlm.nih.gov/pmc/ articles/PMC3744307/

21. Carthery-Goulart MT, Anghinah R, Areza-Fegyveres R, Bahia VS, Brucki SM, Damin A, et al. Performance of a Brazilian population on the test of functional health literacy in adults. Rev Saúde Pública. 2009;43(4):631-8. DOI: http://dx.doi.org/10.1590/S0034-89102009005000031

22. Geboers B, Brainard JS, Loke YK, Jansen CJ, Salter C, Reijneveld SA, et al. The association of health literacy with adherence in older adults, and its role in interventions: a systematic meta-review. BMC Public Health [Internet]. 2015 [cited 2017 sept 30];15:903. Available from: https://www.ncbi.nlm.nih.gov/pubmed/26503456

23. Macabasco-O'Connell A, DeWalt DA, Broucksou KA, Hawk V, Baker DW, Schillinger D, et al. Relationship between literacy, knowledge, self-care behaviors, and heart failure-related quality of life among patients with heart failure. J Gen Intern Med [Internet]. 2011 [cited 2017 sept 30];26(9):979-86. Available from https://www.ncbi. nlm.nih.gov/pmc/articles/PMC3157534/

24. Kale MS, Federman AD, Krauskopf K, Wolf M, O'Conor R, Martynenko M, et al. The association of health literacy with illness and medication beliefs among patients with chronic obstructive pulmonary disease. PLoS One [Internet]. 2015 [cited 2017 sept 30];10(4):e0123937. Available from https://www.ncbi.nlm.nih.gov/pmc/articles/ PMC4411058/

25. McNaughton CD, Cawthon C, Liu SKD, Storrow AB, Roumie CL. Health literacy and mortality: a cohort study of patients hospitalized for acute heart failure. J Am Heart Assoc [Internet]. 2015 [cited 2017 sept 30];18;4(6):e000682. Available from: https://www.ncbi.nlm.nih.gov/pmc/articles/PMC4599411/

26. Peterson PN, Shetterly SM, Clarke CL, Bekelman DB, Chan PS, Allen LA, et al. Health literacy and outcomes among patients with heart failure. JAMA. 2011;305(16):1695-701. DOI: 10.1001/jama.2011.512

27. Searle J, Frick J, Möckel M. Acute heart failure facts and numbers: acute heart failure populations. Esc Heart Failure. 2016;3(2):65-70. DOI: http://doi.org/10.1002/ ehf 2.12092

28. McBain H, Shipley M, Newman S. The impact of self-monitoring in chronic illness on healthcare utilisation: a systematic review of reviews. BMC Health Serv Res. 2015:565. DOI: http://doi:10.1186/s12913-015-1221-5

29. Cardoso J, Novaes M, Ochiai M, Kelly R, Morgado P, Munhoz R, et al. Chagas cardiomyopathy: prognosis in clinical and hemodynamic profile C. Arq Bras Cardiol [Internet]. 2010 [cited 2018 June 10]; 95(4):518-23. Available from: http://www.scielo.br/scielo.php?script=sci_arttext\&pid=S0066-782X2010001400015\&lng=en

30. Calha AGM. Modes of acquisition of health literacy skills in informal learning contexts. Rev Esc Enferm USP [Internet]. 2014 [cited 2017 Oct 01];48(n.spe2):100-6. Available from: http://www.scielo.br/scielo.php?script=sci_arttext\&pid=S0080-62342014000800100\&lng=en 